\title{
Upaya Transformasi Masyarakat Indonesia Pada Era Masyarakat 5.0 Berdasarkan Ajaran Yesus tentang Kerajaan Allah
}

\author{
Stefanus Rachmat Budiman ${ }^{1}$, Alfredo Lamborgini Elya ${ }^{2}$, Dewi Juliati Bate'e ${ }^{3}$ \\ Sekolah Tinggi Teologi INTI Bandung \\ Korepondensi: stefanusbudiman@gmail.com ${ }^{1}$, lamborghini.elya@gmail.com², \\ dewijuliati127@gmail.com ${ }^{3}$
}

\begin{abstract}
Abstrak: Terkoneksinya antara dunia fisik dengan dunia digital sebagai ciri dari Masyarakat 5.0 memicu perubahan-perubahan kultur dalam kehidupan masyarakat. Hal ini memerlukan respons Gereja yang berbeda, baik pada konteks teologi maupun praksis transformasi. Upaya transformasi terlihat cenderung bersifat parsial, di antara pengutamaan pemberitaan Injil atau tanggungjawab sosial. Hal ini terjadi karena adanya tarik menarik pengaruh teologi yang bersifat membedakan (polarization) ataupun menyamakan (equalization) diantara keduanya, sehingga dampak transformasi kurang optimal. Dibutuhkan model upaya transformasi yang bersifat integratif dan relevan. Penelitian mencoba mengkaji kehadiran Kristus dalam menyatakan Kerajaan Allah tidak sebatas berita pertobatan juga melibatkan diri-Nya dalam pergumulan sosial masyarakat. Praksis-Nya melampaui upaya ekualisasi ataupun polarisasi tetapi menekankan urgensi integrasi keduanya. Praksis ini akan ditawarkan menjadi model transformasi masyarakat di Indonesia. Penelitian dilakukan melalui metode hermeneutika dengan memberi tekanan pada analisis historis dan sosial terhadap beberapa bagian teks tertentu dalam Injil berkenaan dengan kehadiran Kerajaan Allah yang digagas Yesus.
\end{abstract}

Kata kunci: Indonesia, kerajaan Allah, masyarakat 5.0, transformasi

Abstract: The connection between the physical world and the digital world as a characteristic of Society 5.0 has triggered cultural changes in the lives of society. These cultural changes will require a different Church response, be it in theological context as well as transformation praxis. The existing transformation efforts is often seen as partial, between prioritizing the preaching of the gospel or social responsibility. This is due to the tug-of-war effect between the two theological influences with differentiating nature (polarization) or equalizing nature (equalization), so that the transformation impact is perceived as nonoptimal. A model of transformative effort that is integrative and relevant is needed. The research tries to examine the presence of Christ in proclaiming the Kingdom of God which was not only limited to conveying the message of repentance but also involved Himself in the social struggles of society. His praxis go beyond equalization or polarization and instead emphasize the urgency of the integration of the two. This praxis will be offered as a society transformation model in Indonesia. This research is conducted by hermeneutic method with emphasize on historical and social analysis towards certain texts of the Bible regarding the presence of the Kingdom of God initiated by Jesus.

Keywords: Indonesia, kingdom of God, society 5.0, transformation 


\section{PENDAHULUAN}

Memasuki era masyarakat 5.0., fenomena perubahan adalah keniscayaan. Pemahaman masyarakat era 5.0., pertama diaktualkan dalam Kabinet Jepang dan dicirikan dengan melarutnya peran teknologi di dalam masyarakat. Ketika teknologi internet, 'Kecerdasan Buatan,' serta peran Big Data yang berkelindan menjadi bagian hidup masyarakat, maka terciptalah apa yang dipahami sebagai era Masyarakat 5.0. Teknologi digadang untuk membantu masyarakat memecahkan masalah sosial, sehingga berharap terciptanya kondisi hidup yang lebih baik. ${ }^{1}$ Terintegrasinya dunia virtual dengan dunia nyata melalui teknologi, patut diapresiasi karena harus diakui memberi kemudahan di dalam aktivitas hidup, seperti pada proses pendidikan ${ }^{2}$, pengaturan aset intelektual, ${ }^{3}$ atau pencarian informasi melalui internet atau ebook. ${ }^{4}$

Terintegrasinya dunia virtual dan fisik, nampaknya telah memberi ruang terciptanya komunitas sosial baru dunia maya yang disebut warganet (netizen). Eksistensi warganet merupakan perluasan dari komunitas dunia nyata. Mereka hidup berjejaring dan berinteraksi melalui sosial media seperti Facebook, Twitter, Instagram, Whatsapp dan Tik-tok. Kondisi ini mampu mencipta ghetto-ghetto sosial dunia virtual, yang dihuni warganet yang merasa cocok, sesuai dan pas dengan keyakinannya. Melalui komunitasnya, mereka mampu mengungkapkan pendapat, keyakinan, kegelisahan ataupun ideologinya secara bebas. Kebebasan dalam berekspresi melalui media sosial di ruang virtual, mampu menjadi tonggak demokrasi bagi warganet berekspresi, tetapi juga rentan disalahgunakan. Ketika kebebasan berekspresi diselewengkan, mencuatlah dampak sosial dunia

${ }^{1}$ Faulinda Ely Nastiti dan Aghni Rizqi Nimal Abdu, "Kajian: Kesiapan pendidikan Indonesia menghadapi era society 5.0," Edcomtech 5, no. 1 (2020): 61-66.

${ }^{2}$ Neil Selwyn, Stephen Gorard, dan John Furlong, Adult learning in the digital age: Information technology and the learning society (Routledge, 2006).

${ }^{3}$ Jeffrey $\mathrm{H}$ Matsuura, Managing intellectual assets in the digital age (Artech House, 2003).

${ }^{4}$ Jeff Gomez, Print is dead: Books in our digital age (Palgrave Macmillan, 2008). virtual. Bentuk ungkapan kebencian, sikap intoleransi, hoax, perundungan (bullying), adalah sedikit dari fenomena ini. ${ }^{5}$ Bahkan dalam tingkat yang lebih akut memunculkan tindak kriminalitas dunia maya seperti skimming, ${ }^{6}$ pishing, bom email, peretasan serta bentuk kejahatan dunia maya lainnya.

Ketika masalah dunia maya berkelindan dengan masalah dunia nyata, seperti terorisme, sikap intoleran, kekerasan, ketidakadilan, kemiskinan, korupsi, maka terpotretlah masalah sosial masyarakat era 5.0. Jika sudah seperti ini, jangankan memberikan solusi, melihat saja persoalan sosial yang begitu bertumpuk sudah membuat 'mulas' dan 'miris' masyarakat. Lantas masihkah ada cara yang bisa memberi harapan bagi kondisi masyarakat yang lebih baik, beradab dan berkeadilan.

Peran Gereja menjadi signifikan untuk mengupayakan transformasi masyarakat yang lebih baik, beradab dan berkeadilan. Gereja dipahami sebagai komunitas umat yang telah diperbaharui Kristus, terbuka dan mampu merangkul perbedaan dengan sesama sebagai penyandang gambar Sang Pencipta. ${ }^{7}$ Kondisi ini juga bisa menjadi kesempatan bagi Gereja menunjukkan memberi solusi dan harapan di dalam era digital. ${ }^{8}$ Upaya transformasi umumnya diimplementasikan Gereja melalui kesaksian Injil serta keterlibatan sosial (social concern). Hanya saja upaya transformasi sering "terjebak" pada sikap membedakan (polarization) atau menyamakan (equalization) diantara keduanya. Sikap bisa timbul karena adanya tarik-menarik pengaruh teologi tertentu dalam Gereja.

Pertanyaannya, apakah upaya transformasi masyarakat yang dilakukan Gereja dengan pola

${ }^{5}$ Daniel J Solove, The future of reputation (Yale University Press, 2008).

${ }^{6}$ Dian Alan Setiawan, "Perkembangan Modus Operandi Kejahatan Skimming Dalam Pembobolan Mesin Atm Bank Sebagai Bentuk Kejahatan Dunia Maya (Cybercrime)," Era Hukum-Jurnal Ilmiah Ilmu Hukum 16, no. 2 (2019).

${ }^{7}$ Yohanes Krismantyo Susanta, "Gereja Sebagai Persekutuan Persahabatan Yang Terbuka Menurut Jürgen Moltmann," Visio Dei: Jurnal Teologi Kristen 2, no. 1 (2020): $105-126$.

${ }^{8}$ Giulia Isetti et al., Religion in the Age of Digitalization (New York: Routledge, 2021). 
dan prinsip membedakan dan menyamakan telah optimal? Karena tindakan menyamakan dan membedakan seperti yang diungkapkan Melba Maggay, ${ }^{9}$ cenderung menjadikan upaya transformasi masyarakat oleh Gereja menjadi tumpul, prematur dan tidak optimal. Kondisi ini nampaknya menuntut adanya suatu alternatif akan prinsip upaya transformasi, sehingga upaya transformasi masyarakat yang dilakukan Gereja lebih optimal dan signifikan.

Tujuan penulisan bukanlah untuk mengabaikan upaya transformasi masyarakat yang telah dilakukan ataupun menafikan prinsipprinsip penelitian transformasi masyarakat seperti yang dituliskan Maggay. ${ }^{10}$ Tulisan mencoba menanggapi bagaimana dalam upaya transformasi masyarakat tidak terjebak, baik dalam sikap membedakan ataupun sikap menyamakan diantara kesaksian Injil ataupun keterlibatan sosial. Penelitian dilakukan dalam mengupayakan suatu teologi transformasi yang konstruktif dan integratif. Tujuannya guna menawarkan suatu teologi transformasi yang integratif dan holistik dari kehadiran Kerajaan Allah melalui praksis yang digagas Yesus. Sehingga tulisan tidaklah menafikan tetapi mencoba berkontribusi dalam upaya meluaskan wahana tafsir yang telah ada.

\section{METODE}

Di dalam penulisan artikel, penelitian mengambil dari beberapa bagian teks dalam Injil. Teks-teks yang dimaksudkan, khususnya berkenaan dengan kehadiran Kerajaan Allah melalui pelayanan Yesus. Kemudian teks-teks akan dianalisis melalui metode hermeneutika dengan penekanan pada aspek historis dan sosial. Ini penting dilakukan karena teks bukan produk jadi yang "dilempar dari langit" tetapi melalui proses pendokumentasian panjang dan berliku. Proses panjang melalui bingkai waktu dan peristiwa berbeda, situasi sosial dan historis

\footnotetext{
${ }^{9}$ Melba Padilla Maggay, Transformasi Masyarakat: Refleksi Keterlibatan Sosial Kristen, Edisi pert. (Jakarta: Cultivate Publishing, 2004), 9-12.

${ }^{10}$ Maggay, Transformasi Masyarakat: Refleksi Keterlibatan Sosial Kristen.
}

berbeda, serta ditujukan bagi kebutuhan komunitas yang berbeda. ${ }^{11}$

Dalam implementasinya, upaya analisa pada teks-teks Injil akan didukung juga dengan jurnaljurnal serta buku-buku teologi dan juga bukubuku sosial tertentu. Hasil analisis hermeneutika atas teks akan ditarik suatu simpulan berkenaan dengan Kerajaan Allah, serta bagaimana prinsip dan praksisnya diaktualkan melalui pelayanan Kristus pada konteksnya. Kemudian dari penelitian akan ditarik prinsip penting yang dijadikan dasar dalam upaya transformasi dalam konteks Masyarakat 5.0.

Tulisan tidaklah bermaksud untuk menganulir atau menafikan wahana tafsir terdahulu dalam upaya transformasi, tidak juga menganggap usaha transformasi tersebut tidak penting. Semua upaya yang telah dilakukan sekuat tenaga tersebut patut diapresiasi. Maksud penelitian dilakukan sebagai usaha meluaskan wahana tafsir dan mencoba memberi kontribusi dengan menawarkan gagasan holistik kesaksian Kerajaan Allah melalui praksis yang digagas Yesus. Suatu integrasi berita Injil dan tanggungjawab sosial, dalam mengupayakan transformasi yang lebih membumi dan dirasakan optimal di Indonesia.

\section{PEMBAHASAN}

\section{Gereja dan Upaya Transformasi Masyarakat}

Secara faktual masyarakat Indonesia tengah menghadapi masalah sosial yang kompleks. Masalah sosial yang dimaksudkan antara lain intoleransi, terorisme, kemiskinan, ketidakadilan, korupsi, tampak secara kasat mata. Pada ranah virtual berhadapan dengan masalah yang meresahkan, seperti hoax, ujaran kebencian, perundungan (bully), serta bentuk-bentuk kejahatan dunia maya (cyber crime) lainnya. Problem ini dirasakan tidak semakin mereda tapi meningkat eskalasinya, bahkan semakin masif dan cenderung sulit dikendalikan.

${ }^{11}$ Michael J Gorman, Elements of biblical exegesis: A basic guide for students and ministers (Baker Academic, 2020), 113. 
Patut dipahami bahwa masalah-masalah sosial pada masyarakat terbentuk tidak dengan tiba-tiba dan tanpa sebab. ${ }^{12}$ Ini berlaku bagi dunia virtual ataupun fisik. Sikap korup manusia yang juga didera hidup sulit mampu menjadi katalis pemicunya. Dalam kondisi buruk seperti ini, sikap optimis dan berharap tidaklah cukup. Dibutuhkan sikap terbuka dan siap bekerja keras untuk mengubahnya untuk terciptanya kondisi masyarakat yang lebih baik, beradab dan berkeadilan.

Pemerintah maupun lembaga masyarakat bukan tidak bekerja. Mereka telah berusaha dan bekerja keras dalam upaya transformasi masyarakat. Sederet usaha telah dilakukan, umpamanya dalam bidang ekonomi melalui program reduksi pajak, Bantuan Sosial (Bansos), Kartu Prakerja, Bantuan Langsung Tunai (BLT). Dalam menangani sikap intoleransi dibuat Densus 88. Untuk menangani korupsi yang tidak pernah surut dibentuk KPK. Sedangkan untuk mengatasi masalah dunia virtual dilakukan melalui UU ITE, juga melalui Pengembangan Satuan Unit Cyber Crime. ${ }^{13}$ Meski bukan tanpa kritik, nampaknya perlu mengapresiasi segala usaha dan kerja keras ini.

Dalam upaya transformasi ini, Gereja juga hadir mengambil bagian. Gereja dipahami sebagai wakil Allah untuk menyapa manusia. Allah menyapa manusia yang terpuruk untuk menyatakan kasih dan kuasa-Nya dalam upaya transformasi. Alkitab menuturkan bagaimana Allah mengajak umat aktif terlibat dalam transformasi ciptaan yang telah dinodai dosa dan bukan lari dari tanggungjawab. Pada masa Perjanjian Lama secara khusus Allah mengutus nabi untuk mengkritisi ketidakadilan, mengimbau menaati hukum, membela yang miskin, yang lemah dan tertindas, dan mengupayakan kesejahteraan bangsa. $^{14}$

${ }^{12}$ Stefanus Rachmat Budiman, "Problem Keadilan Sosial Dalam Nubuat Kitab Mika," Jurnal Transformasi 14, no. 1 (2019): 101.

${ }^{13}$ M. A. Azis, "Pengembangan Satuan Unit Cyber Crime,” Jurnal Litbang POLRI 22, no. 1 (2019): 408-459.

${ }^{14}$ Ridwan Henry Simamora, "Gereja Dan Transformasi Kristen Suatu Tinjauan Kristis Terhadap Misi Gerakan Transformasi," Missio Ecclesiae 2, no. 1 (2013): 109.
Kemudian masa Perjanjian Baru melalui Kristus dengan menghadirkan Kerajaan Allah melalui praksis pelayanan-Nya. Masa kini Gereja dipanggil untuk mengupayakan shalom serta menjadi garam dan terang. ${ }^{15}$

Gereja perlu memahami bahwa transformasi masyarakat sebagai fokus misi yang diamanatkan Yesus. Menarik menyitir apa yang dituliskan oleh Jerry Pillay, ${ }^{16}$ bahwa "The church as a transformation and change agent." Dalam perannya sebagai agen perubahan, Gereja terfokus untuk mengkomunikasikan Kabar Baik pada iman dan pertobatan, mengedukasi manusia agar taat melakukan apa yang diajarkan Yesus. Asumsinya, dengan melakukannya akan mampu membawa transformasi kehidupan baik secara fisik, sosial dan spiritual.

\section{Transformasi Masyarakat Antara Membedakan dan Menyamakan}

Pemahaman bahwa Gereja sebagai agent of transformation, telah mendorong Gereja melakukan upaya transformasi masyarakat sepanjang masa. Bahkan secara eksplisit bukan hanya mendorong, juga untuk terus mengubah paradigma misinya. Upaya transformasi paradigma misi yang dianggap signifikan ini, bisa dilihat dari tulisan David Jacobus Bosch. ${ }^{17}$ Rentang perubahan paradigma misi digambarkan dari masa awal sampai masa modern, khususnya ketika Gereja bergumul dengan tantangan yang 'memaksanya' untuk mengubah paradigma.

Secara umum, implementasi upaya transformasi masyarakat oleh Gereja mengerucut pada kesaksian Injil dan keterlibatan sosial (social concern). Melalui kesaksian Injil manusia bisa mengalami penebusan dan pembaharuan rohani di dalam Kristus (Rm. 1:16-17; 2Kor. 5:17). Sedangkan melalui social concern, Gereja dituntut

${ }^{15}$ Kalis Stevanus, "Mengimplementasikan Pelayanan Yesus dalam Konteks Misi Masa Kini Menurut Injil Sinoptik,” FIDEI: Jurnal Teologi Sistematika dan Praktika 1, no. 2 (2018): 284-298.

${ }^{16}$ Jerry Pillay, "The church as a transformation and change agent," HTS Theological Studies 73, no. 3 (2017): 1.

${ }^{17}$ David J Bosch, Transforming mission: Paradigm shifts in theology of mission (Orbis books, 2011). 
berperan aktif dan terlibat dalam upaya memperbaharui bumi yang menjadi ciptaan Allah (Kol. 1:15-16).

Hanya saja upaya transformasi yang dilakukan dengan dana, tenaga yang baik serta kesungguhan hati, cenderung terjebak dalam prinsip menyamakan (equalization) ataupun prinsip membedakan (polarization) diantara kesaksian Injil dan keterlibatan sosial. Akibatnya, upaya transformasi menjadi tumpul dan prematur. Prinsip menyamakan adalah suatu prinsip yang menganggap pemberitaan Injil sama dengan upaya sosial. Sedangkan prinsip membedakan adalah suatu prinsip memahami kesaksian Injil sebagai suatu yang terpisah dengan upaya sosial. Prinsip menyamakan atau membedakan diantara keduanya ini, menurut Melba Padilla Maggay, ${ }^{18}$ telah menjadikan transformasi masyarakat tidak optimal.

Menyamakan kesaksian Injil dengan keterlibatan sosial demi untuk martabat manusia dan keadilan nampaknya kurang tepat. Upaya sosial melalui tindakan membebaskan manusia dari struktur yang menindas, lebih tepat dilihat sebagai aspek kosmik dari kesaksian dan keselamatan. ${ }^{19}$ Alasannya, Injil adalah suatu berita yang disuarakan secara verbal, suatu peristiwa spiritual penebusan Yesus yang harus dieksplanasi, dipahami dengan benar serta menuntut respon pertobatan manusia.

Ada tendensi begitu optimis dari prinsip menyamakan, dimana pembaharuan rohani seseorang otomatis berdampak pada lingkungannya. Transformasi dipahami berdampak sosial secara spontan dan signifikan pada konteks masyarakatnya. Umpamanya, dengan memakai narasi pertemuan Yesus dengan Zakheus (Luk. 19:1-10) yang langsung berdampak pada lingkungan sosialnya. Zakheus langsung mengembalikan uang haram hasil pemerasannya. Atau bisa juga peristiwa pertemuan Yesus dengan perempuan Samaria yang disitir David Setiawan $^{20}$ dari tulisan Harming, ${ }^{21}$ yang

\footnotetext{
${ }^{18}$ Maggay, Transformasi Masyarakat: Refleksi Keterlibatan Sosial Kristen.

${ }^{19}$ Ibid.

${ }^{20}$ David Eko Setiawan, "Dampak Injil Bagi Transformasi Spiritual Dan Sosial,” BIA': Jurnal Teologi dan Pendidikan Kristen Kontekstual 2, no. 1 (2019): 84.
}

dipahami memiliki dampak pada konteks kehidupan sosial perempuan Samaria.

Hanya secara faktual, tanpa menafikan prinsip ini, di lapangan realitasnya tidaklah selalu demikian. Pengalaman pertobatan seseorang perlu berproses untuk akhirnya memiliki dampak sosial pada lingkungannya. Iman pertobatan tidaklah otomatis menumbuhkan kesadaran yang mendorong akan implikasi sosial yang lebih jauh. Minimnya pemahaman iman berdampak pada kerdilnya kerohanian, juga minimnya dampak sosial di lingkungan. Patut diperhatikan juga bahwa problem sosial dalam masyarakat adalah suatu struktur raksasa yang kuat, masif dan terorganisir. Kelaparan, korupsi, kemiskinan, penindasan, masalah ekologi, tidaklah cukup diselesaikan oleh individu-individu yang hanya bermodalkan tekad untuk mengubahnya. Injil penting, perlu dan mutlak, tetapi bukan berarti abai pada sikap korektif dan keterlibatan dalam kehidupan sosial dan politik. Kesadaran korektif dalam sosial dan politik ini perlu ditanamkan melalui pembinaan secara sistematis dan tidak akan tumbuh natural.

Lalu bagaimana dengan prinsip kedua yang bersifat membedakan (polarization) antara kesaksian Injil dan keterlibatan sosial. Prinsip inipun bisa menjadikan upaya transformasi tumpul dan prematur. Gagasan ini berpotensi membangun sikap dualisme yang memilah antara sifat spiritual dan kekal dengan sifat fana dan temporer. Sikap ini di samping menafikan gagasan holistik Injil dan pelayanan Yesus ${ }^{22}$, juga gagal memahami transformasi sosial yang dilakukan-Nya secara utuh. Orang bisa memprioritaskan pemberitaan Injil karena dianggap rohani dan kekal, sedangkan berpolitik, terlibat membantu orang miskin dan carut marut sosial adalah sekunder karena dianggap fana dan temporer. Pemahaman dikotomi akan menilai yang satu lebih penting dari pada yang lain ataupun sebaliknya. Upaya yang dilakukan akan terjebak sikap prioritas

${ }^{21}$ Harming Harming, "Metode Penginjilan Yesus Dalam Injil Yohanes 4: 1-42," Evangelikal 1, no. 2 (2017): $162-169$.

${ }^{22}$ Stevanus, "Mengimplementasikan Pelayanan Yesus dalam Konteks Misi Masa Kini Menurut Injil Sinoptik." 
pada yang dianggap penting, dan abai pada yang dianggap sekunder. Upaya akhirnya dilakukan tidak sepenuh hati dan bermuara pada tumpulnya transformasi.

Maggay menggambarkan bagaimana upaya transformasi tidak optimal karena terjebak pada prinsip membedakan (polarization) atau menyamakan (equalization). Upaya transformasi yang telah dilakukan melalui prinsip Garam dan Terang oleh Franciscus Assisi, Teologi Pembebasan di Amerika Latin oleh Gustavo Gutiérrez Merino, membangun konsensus kebudayaan Kristen melalui Mandat Kebudayaan oleh kelompok Reform, serta Model Pembangunan sebagai implementasi belas kasih oleh Mother Teresa, ${ }^{23}$ baik dan patut diapresiasi. Semuanya telah dilakukan secara serius serta kerja keras tanpa pamrih. Hanya saja semua upaya dampaknya terbatas jika dilakukan secara spasial melalui prinsip menyamakan atau membedakan. Sehingga upaya membangun shalom bagi masyarakat yang lebih baik, berkeadilan, beradab menjadi tidak optimal.

\section{Integrasi Kesaksian Injil dan Tanggungjawab Sosial}

Jika prinsip menyamakan dan membedakan dianggap tidak ideal, adakah prinsip lain yang bisa ditawarkan. Di sini prinsip Kehadiran Kerajaan Allah yang digagas Yesus dalam pelayanan-Nya bisa dijadikan model. Praksis yang digagas Kristus melalui pelayanan-Nya sebagai implementasi Kerajaan Allah menarik untuk didalami. Upaya ini dilakukan sebagai penyegaran dalam transformasi yang mungkin dirasakan kurang optimal. Sehingga harapannya upaya transformasi bisa relevan dan membumi di era Masyarakat 5.0.

Meski Kerajaan Allah tidak didefinisikan dengan gamblang, namun dominan dalam Injil, khususnya di dalam pemberitaan Yesus. Ini nampak tertulis seperti pada Matius 4:17, 4:23, 5:20, 6:10, 7:21, 12:28, 13:11, 25:31, 25:34; Markus 1:14-15, 4:30-34, 9:1; Lukas 4:42-44,

\footnotetext{
${ }^{23}$ Maggay, Transformasi Masyarakat: Refleksi Keterlibatan Sosial Kristen.
}

7:18-35, 9:1-6; Yohanes 18:28-38a. ${ }^{24}$ Pemahaman ini sejalan juga dengan apa yang diungkapkan oleh Richard Foster ${ }^{25}$ bahwa berita Kerajaan Allah dominan dalam pemberitaan Yesus. Bahkan George Ladd menyatakan Kerajaan Allah sebagai kajian menarik dan marak diperdebatkan. ${ }^{26}$ Konsekuensinya, upaya untuk memahami Kerajaan sebagai fokus dari pemberitaan Yesus adalah sesuatu yang tidak bisa dinafikan. ${ }^{27}$

Kerajaan Allah dalam Perjanjian Baru tidaklah muncul dengan tiba-tiba, tapi memiliki benang merah dengan Perjanjian Lama. Dalam dunia Perjanjian Lama, pemahaman Kerajaan Allah memiliki paradigma yang dinamis. Pada konteks Yudaisme, Kerajaan Allah adalah gagasan Allah yang hadir memerintah di dunia, hanya bukan secara pribadi. Seperti umpamanya pada teks Yesaya 24:23 menulis: "Tuhan semesta alam akan memerintah," yang dalam Targum diubah menjadi "Kerajaan Allah akan memperlihatkan diri." Yesaya 40:9 menulis "Lihat Allahmu" yang dalam Targum diubah menjadi: "Kerajaan dari Allahmu telah menjelma." Keduanya menunjukkan bahwa gagasan Kerajaan Allah identik dengan kuasa atau pemerintahan Allah. Pada masa pembuangan Kerajaan Allah menjadi harapan eskatologis, dimana Allah bertindak menolong, menghibur (Mi. 2:12-13; Yes. 40:9-11; Ezr. 34:11-19), dan membebaskan (Yes. 40:9-11, 52:7; Ez. 20:33,37; Zef. 3:15; Za. 9:9). Sedangkan pada pasca pembuangan, bersifat substansial dan transenden, dimana Allah akan mendirikan kerajaan yang tak akan musnah, tidak takluk pada bangsa lain, bersifat kekal (Dan. 2:44, 4: 31, 34) yang kemudian akan diberikan kepada Anak Manusia (Dan. $7: 14,18){ }^{28}$

${ }^{24}$ I Made Priana, "Misi Gereja Menghadirkan Kerajaan Allah di Bumi," SANCTUM DOMINE: JURNAL TEOLOGI 4, no. 1 (2016): 12.

${ }^{25}$ Richard J Foster, Money, Sex $\mathcal{E}$ Power: The Challenge of the Disciplined Life (San Francisco: Harper \& Row Publisher, 1985), 19.

${ }^{26}$ George Eldon Ladd, Injil Kerajaan (Yayasan Penerbit Gandum Mas, 1994), 7.

${ }^{27}$ Robi Panggarra, "Kerajaan Allah Menurut InjilInjil Sinoptik," Jurnal Jaffray 11, no. 1 (2013): 110.

${ }^{28}$ Priana, "Misi Gereja Menghadirkan Kerajaan Allah di Bumi." 
Dengan demikian Kerajaan Allah dapat disimpulkan sebagai eksisnya pemerintahan Allah dan berimplikasi kebebasan, penebusan, keselamatan, absennya penindasan atau pemerasan karena kuasa pertolongan-Nya. Melalui pemahaman ini dapatlah dipahami jika melihat Yesaya 52:7, bagaimana berita yang begitu indah ini sangat dinantikan umat. Suatu berita yang mampu membangun harapan, keyakinan akan kuasa Allah yang menyelamatkan, ${ }^{29}$ yang dinantikan untuk bisa terealisasi.

Dalam kondisi yang menantikan penuh harap ini, Yesus hadir memberitakan kehadiran Kerajaan Allah. Yesus hadir sebagai representasi Kerajaan Allah dalam upaya transformasi masyarakat. Pernyataan-Nya "jika Aku mengusir setan dengan kuasa Allah, maka sesungguhnya Kerajaan Allah sudah datang kepadamu” (Mat.12:28; Luk.11:20), menunjukkan bahwa pekerjaan pengusiran roh jahat memastikan bahwa masa Kerajaan Allah sudah dimulai. Yesus, Dialah representasi Kerajaan Allah, Dialah Mesias dan Raja yang dinantikan oleh umat, dan kini menyatakan diri-Nya.

Menarik melihat tulisan Lukas 3:22 "Engkau Anak-Ku yang Kukasihi, kepada-Mulah Aku berkenan," yang merupakan kutipan dari Mazmur 2:7 dan Yesaya 42:1. Menurut A. M. Hunter, ${ }^{30}$ Mazmur 2:7 merupakan rumusan dari penahbisan dari raja Mesianis, sedangkan Yesaya 42:1 sebagai penahbisan Hamba Tuhan. Sitiran Perjanjian Lama oleh Lukas tidaklah kebetulan tetapi di bawah bimbingan Roh Allah. Jika dirangkum keduanya memberi arti bahwa Yesus hadir untuk mengemban misi Mesias-Hamba. Pernyataan "Aku telah menaruh Roh-Ku ke atasnya" (Yes.42:1, 61:1), yang juga dikutip dalam Lukas 4:18, dipahami sebagai melengkapi Yesus dengan kuasa Allah. Misi pelayanan Yesus, menyangkut pemberitaan maupun pekerjaanNya, adalah misi dan pelayanan yang disertai kuasa Allah. Ia hadir untuk mentransformasi masyarakat dengan melawan segala bentuk ketidakadilan, penindasan, tetapi juga untuk

\footnotetext{
${ }^{29}$ Ibid.

${ }^{30}$ A. M. Hunter, Memperkenalkan Teologi Perjanjian Baru (Jakarta: BPK Gunung Mulia, 1999), 5.
}

menyatakan yang baik kepada yang tertindas, seperti yang diungkapkan dalam nyanyian pujian Maria (Luk. 1:46-55).

Kristus hadir dalam kondisi manusia yang buruk dan terpuruk secara moral dan sosial. Secara moral nampaknya umat melakukan ibadah, tetapi hati mereka jauh dari Tuhan (Mat. 15:8-9). Moralitas terpuruk, Bait Allah yang seharusnya menjadi rumah doa dan penata moral, menjadi sarang mamon (Yoh. 2:14-16). Sedangkan hidup pemimpin agama dipandang munafik (Mat. 23:22-32), meletakkan Taurat pada umat tetapi mereka tidak melakukannya (Mat. 23:3-4). Ibadah dilakukan agar dipuji dan dihormati (Mat. 23:5-7). Ketika Allah mengutus para nabi, orang bijak dan ahli Taurat untuk menegur, mereka justeru menganiayanya. Yesus mengingatkan bahwa tindakan tersebut akan mendatangkan hukuman yang akan diterima (Mat. 23:33-36).

Secara sosial mereka hidup dalam kemiskinan dalam arti luas. Dalam khotbah Yesus di bukit tentang kata "miskin" (Luk. 6:20, 7:22), bisa diartikan miskin secara spiritual dan miskin secara jasmani. ${ }^{31}$ Mereka juga miskin dalam hak akibat tindasan politik, tidak menjadi kepala seperti janji Allah tetapi menjadi ekor (Ul. 28:13). Bukankah mereka di bawah jajahan Romawi, tidak memiliki apa pun yang dapat dibanggakan, bahkan hak mereka terbengkalai dan tidak dipedulikan.

Kristus hadir memberitakan "pertobatan" (Mat. 4:17), bahkan menekankan juga pentingnya "percaya" (Mrk. 1:15). Pertobatan penting sebagai ekspresi perubahan hati yang korup. Transformasi menyangkut masalah hati yang dipahami sebagai akar penyebab keterpurukan. Yesus mengungkap bahwa tindakan etis dan moral adalah ekspresi hati (Mat. 15:18-19). Yesus hadir bukan hanya sebagai penyelamat bagi umat manusia (Mat. 1:21), juga untuk menghancurkan kuasa iblis yang mencengkeram manusia. Hal ini selaras dengan penyataan-Nya bahwa "jika Aku mengusir setan dengan kuasa Allah, maka sesungguhnya Kerajaan Allah sudah datang kepadamu" (Mat. 12:28; Luk. 11:20). Kehadiran

${ }^{31}$ Hengki Wijaya, "Misi Dan Pelayanan Sosial: Manakah yang lebih Penting?," in Sekolah Tinggi Theologia Jaffray (Sekolah Tinggi Theologia Jaffray, 2017), 121. 
Yesus sebagai representasi kehadiran Kerajaan Allah bertujuan untuk menaklukkan dosa, iblis dan maut yang sudah mencengkeram manusia. ${ }^{32}$ Transformasi dilakukan Yesus selain dimulai dari dalam, dari sebab dan akarnya, juga bertujuan membebaskan manusia dari cengkeraman kuasa kerajaan kegelapan.

Berita pengharapan Injil Kerajaan tidaklah tertuju hanya kepada umat Israel tetapi juga bagi bangsa lain. Indikasi ini nampak seperti dalam Injil Matius yang dianggap kental dengan keyahudiannya. Matius menyematkan orang yang non-Yahudi seperti Tamar, Rahab, Rut, dan Batsyeba dalam silsilahnya. Juga kehadiran orang Majus yang mencari Yesus, penyembuhan hamba perwira dan anak seorang perempuan Kanaan yang bukan Israel. Kemudian Yesus juga melayani cukup lama di Galilea yang dikenal sebagai wilayah bangsa-bangsa lain. Bahkan Matius mengakhiri dengan sebuah amanat Yesus untuk memberitakan Injil kepada seluruh bangsa, yang dalamnya jelas terbuka bagi unsur yang non Yahudi. ${ }^{33}$

Yesus juga hadir menyampaikan kabar pembebasan bagi kaum yang dimarginalkan. Dalam Lukas 4:16 dituliskan bahwa Yesus memberitakan "kabar baik bagi orang miskin, membebaskan tawanan-tawanan, penglihatan bagi yang buta dan kebebasan bagi yang tertindas" (Luk. 4:16). Teks ini dipahami sebagai panggilan sosial-Nya ${ }^{34}$ dan mengingatkan masyarakat dengan tahun Pembebasan atau Yobel (Im. 25:1-55). Dalam tahun Yobel, secara sosial harkat manusia dikembalikan. Tanah dikembalikan untuk memutus kemiskinan, kalaupun miskin hanya untuk satu generasi dan tidak untuk selamanya.

Yesus menghadirkan Kerajaan Allah melalui sikap solidaritas sosial-Nya dengan berinteraksi dan menyatu dengan lingkungannya. Ia memberikan solusi atas masalah-masalah sosial

${ }^{32}$ Ladd, Injil Kerajaan.

${ }^{33}$ Adi Putra, "Memahami Bangsa-bangsa Lain dalam Injil Matius," BIA': Jurnal Teologi dan Pendidikan Kristen Kontekstual 1, no. 2 (2018): 245-246.

${ }^{34}$ H. Susanto, "Panggilan Sosial Gereja Berdasarkan Pelayanan Yesus dalam Lukas 4:18-19: Sebuah Upaya Merevitalisasi Pelayanan Gereja.," Veritas: Jurnal Teologi Dan Pelayanan 19, no. 1 (2020): 97-112. yang terjadi. Ia menyembuhkan penyakit (Mat. $4: 23$; 9:35; 10:1) dan memberi makan orang banyak (Mat. 14:14-21; Mrk. 6:34-44; Yoh. 6:115). Mengapresiasi kelompok yang ditolak oleh masyarakat, misalnya orang kusta (Mat. 8:1-3; Luk. 17:12-14), pemungut cukai dan orang berdosa (Luk.15:1-2), perempuan Samaria (Yoh. 4:9). Bahkan mengidentifikasi diri-Nya dengan kelompok papa yang dimarginalkan, dianggap orang asing, terpenjara, telanjang, kelaparan dan haus (Mat. 25:34-36). Melalui sikap menyatu dengan kaum yang dilupakan dan terbuang, Kerajaan Allah dihadirkan di dalam kehidupan sosial.

Melihat dari praksis Kristus sebagai wujud pengejawantahan kehadiran Kerajaan Allah, tidaklah menunjukkan adanya pemilahan dari apa yang dilakukannya. Pemberitaan Kerajaan Surga (Mat. 10:7-8) maupun pemberitaan tahun pembebasan (Luk. 4:16) yang kental dengan sifat sosial tidaklah menunjukkan polarisasi. Prinsip membedakan atau menyamakan pada praksisnya bisa terjadi karena adanya kecenderungan tarik menarik tafsir teologi tertentu. Kecenderungan tafsir apakah tertuju kepada yang tradisional atau kepada yang lebih modern, mampu menjadikan prinsip berbeda. Muaranya memang berimplikasi pada praksis berbeda dalam bentuk pelayanan Gereja serta bagaimana bentuk keterlibatan Gereja di dalam masyarakat. ${ }^{35}$ Yang pasti, kecenderungan ini menjadikan upaya transformasi tidak optimal karena terjebak sikap mengutamakan dan menomorduakan dalam implementasinya.

Nampaknya tepat pendapat Maggay bahwa pemilahan dalam usaha transformasi tidaklah dikenal dalam Alkitab, ${ }^{36}$ karena keduanya merupakan suatu paket utuh dan terintegrasi. Tidaklah tepat menyatakan bahwa sikap keprihatinan sosial sebagai produk kelahiran baru, yaitu sebagai dampak dari Proklamasi Injil. Tepatnya, social concern merupakan bagian penting dan esensi dalam hadirnya Kerajaan Allah.

\footnotetext{
${ }^{35}$ Christopher J. H. Stott, John R.W. and Wright, Christian mission in the modern world (Downers Grove: InterVarsity Press, 2015), 11-25.

${ }^{36}$ Maggay, Transformasi Masyarakat: Refleksi Keterlibatan Sosial Kristen.
} 


\section{Gereja Sebagai Agen Perubahan Kerajaan Allah}

Jika Kristus telah meletakan prinsip transformasi melalui pemberitaan Injil Kerajaan Allah dan juga keterlibatan sosial, lalu siapakah yang akan meneruskannya. Apakah legacy transformasi hanya menjadi monumen yang terhenti pada Kristus? Lalu siapa yang harus mengambil tongkat estafet untuk melanjutkannya?

Menarik jika memperhatikan dalam Matius 21:43, bagaimana Yesus menyatakan bahwa "Kerajaan Allah akan diberikan pada suatu bangsa yang akan menghasilkan buah Kerajaan." Nampaknya Yesus sedang mengungkapkan gagasan tentang umat yang akan mengambil tongkat estafet Kerajaan Allah. Jika dikaitkan dengan penyataan-Nya pada para murid di Kaisarea, umat yang dimaksudkan adalah Gereja (Mat. 16:18-19). Kepada Gereja inilah Yesus mempercayakan kunci Kerajaan Surga untuk diemban.

Jika pada Perjanjian Lama Kerajaan Allah bekerja hanya melalui Israel sebagai umat pilihan, maka sekarang dalam Kristus Kerajaan Allah dinyatakan kepada bangsa-bangsa lain melalui Gereja. Gereja bukanlah Kerajaan Allah tetapi Kerajaan Allah bekerja dalam Gereja. ${ }^{37}$ Gereja menjadi persekutuan dari para murid Kristus, sebagai suatu komunitas misi dan ciptaan yang baru $^{38}$ menjadi agen perubahan Kerajaan Allah bagi keselamatan dan transformasi masyarakat. Melalui Gereja, Allah melakukan transformasi secara terintegrasi dan menyeluruh. Gereja dalam konteks ini mampu berarak-arak melayani Tuhan, di dalam spirit yang bukan hanya "mewartakan Injil" tetapi juga dengan semangat "membagi roti" kepada sesama. ${ }^{39}$

\footnotetext{
${ }^{37}$ Panggarra, "Kerajaan Allah Menurut Injil-Injil Sinoptik."

${ }^{38}$ Tony Salurante, Dyulius Th Bilo, dan David Kristanto, "Transformasi komunitas misi: Gereja sebagai ciptaan baru dalam Roh Kudus," KURIOS (Jurnal Teologi dan Pendidikan Agama Kristen) 7, no. 1 (2021): 136-148.

${ }^{39}$ Hendrikus Nayuf, "Mewartakan Injil - Menahan Roti: sebuah Catatan Kritis Atas Model Pelayanan Yudas," BIA': Jurnal Teologi dan Pendidikan Kristen Kontekstual 1, no. 2 (2018): 202.
}

\section{Praksis Kehadiran Kerajaan Allah dan Masyarakat 5.0}

Jika kehadiran Kerajaan Allah melalui pelayanan Kristus mampu memberi solusi, harusnya mampu juga menjadi solusi bagi Masyarakat 5.0. Dalam konteks ini peran dan juga kehadiran Gereja sebagai representasi Kerajaan Allah, dirasa strategis dan signifikan dalam upaya transformasi. Peran Gereja penting khususnya dalam mengejawantahkan praksis kehadiran Kerajaan Allah guna menjawab permasalahan dalam masyarakat.

Seperti diungkap di atas bahwa masalah masyarakat tidaklah muncul dengan tiba-tiba. Ada peran dan kontribusi sikap buruk dan korup manusia yang menyuburkannya. Jika dikaitkan dengan kehadiran Kerajaan Allah, berkenaan dengan sikap korup manusia, maka berita Injil bukanlah opsional tetapi keniscayaan. Yesus memahami korupnya manusia, sehingga kesaksian Injil Kerajaan melekat dengan kehadiran-Nya. Pewartaan Injil mengkonfirmasikan bahwa era Kerajaan Allah telah hadir. Hanya melalui karya Yesus, manusia mengalami pembaharuan spiritualitas yang memberi abilitas melawan perilaku korupnya.

Pada era Masyarakat 5.0 yang sarat dengan teknologi, maka melalui jaringan internet Injil bisa disampaikan lebih efektif. Melalui pemanfaatan aplikasi media sosial seperti Youtube, WhatsApp, Facebook, Instagram, Twitter, LinkedIn dan yang paling mutakhir Tik-Tok, upaya menghadirkan Kerajaan Allah melalui kesaksian Injil menjadi semakin luas. Pewartaan Injil tidak lagi dikondisikan jarak dan waktu. Bahkan dengan pemanfaatan sosial media, mampu menerobos batas geografis. Area yang dirasa sulit ataupun hal-hal tertentu yang dianggap menjadi kendala sebelumnya, kini dapat diretas dengan pemanfaatan teknologi.

Pada konteks social concern, khususnya dalam menanggulangi dampak sosial yang diakibatkan teknologi, upaya ini tidaklah kurang pentingnya. Nampaknya apa yang telah dilakukan Gereja sebelumnya seperti berpartisipasi dalam masalah edukasi, keadilan, HAM, ekologi, perlindungan anak, pembangunan masyarakat dan hal lainnya butuh tetap diupayakan. Hanya saja pada 
konteks Masyarakat 5.0, upaya perlu diperluas merambah kepada dunia virtual. Gereja butuh bersifat partisipatoris dalam upaya transformasi masyarakat dalam dunia maya. Hal ini dilakukan khususnya dalam upaya menanggulangi dan mereduksi dampak sosial yang meresahkan seperti hoax, perundungan (bully), ujaran kebencian ataupun bentuk-bentuk kejahatan dunia maya lainnya. Sikap partisipatoris Gereja di dalam dunia virtual, bisa dipahami sebagai mengejawantahkan bagaimana Yesus menyatu dengan masyarakat dalam menjawab masalah yang dihadapi.

Upaya konstruktif dibutuhkan, sehingga dampak sosial dari masalah-masalah tersebut bisa ditekan eskalasinya. Cara yang bisa dilakukan dalam ranah komunitas, umpamanya dengan upaya memberi informasi positif dan menolak berita bohong, membangun kultur keberagaman yang memihak kebebasan serta menentang sikap intoleran. Bisa juga dengan berperan aktif dalam diskusi grup anti hoaks di media sosial, seperti Forum ANti Fitna, Hasut, dan Hoax (FAFHH), Group Indonesian Hoax Buster, atau Grup Sekoci.

Sedangkan pada ranah individu bisa dilakukan dengan misalnya, menjadi pewarta damai, menghindari mengekspos dan mengumbar kehidupan pribadi berlebihan karena hidup bukanlah ajang mempertontonkan kemewahan, berbicara santun dan informatif, mewartakan hal positif dan damai, menghapus konten amoral serta melawan konten-konten negatif lainnya.

Upaya ini butuh dilakukan dengan sikap sepenuh hati, tidak bersikap memilah dan menganggap satu lebih penting dari lainnya. Dengan demikian melalui Gereja, kehadiran Kerajaan Allah bagi masyarakat melalui praksis kesaksian Injil dan keterlibatan sosial, bisa dirasakan dampaknya. Semuanyanya dilakukan dengan satu harapan, upaya transformasi masyarakat bisa terjadi secara optimal.

\section{KESIMPULAN}

Dari uraian di atas berkenaan dengan kehadiran Kerajaan Allah melalui pelayanan yang di gagas Yesus, ada beberapa simpulan yang bisa diberikan.
Pertama, Kristus hadir dalam kondisi masyarakat yang terpuruk secara moral dan sosial. Keterpurukan yang muncul bukan tanpa sebab tetapi dipicu oleh keburukan moral manusia. Hal ini bisa menjadi cerminan keterpurukan masyarakat era 5.0, yang dicengkeram masalah moral dan sosial yang menggurita. Menggurita karena berkelindannya masalah-masalah pada konteks dunia virtual dan juga dunia nyata. Kontribusi keburukan moral manusia berperan menciptakan masalah. Sehingga transformasi menyeluruh dan terintegrasi, bukan hanya pada penyebab juga pada akar masalah perlu diupayakan.

Kedua, Kristus hadir sebagai representasi Kerajaan Allah. Ia hadir sebagai sosok Mesias yang memberitakan tahun rahmat Tuhan untuk membebaskan umat dari penindasan. Transformasi masyarakat melalui kehadiran Kerajaan Allah, dijabarkan melalui praksis berita pertobatan serta membaurnya Yesus dalam masyarakat. Bagi Yesus, upaya transformasi dimulai dari pertobatan hati. Hati dianggap akar keterpurukan moral dan sosial. Kemudian juga melalui tindakan menghisabkan diri secara sosial dengan umat. Dengan demikian kehadiran Kerajaan Allah tidaklah dikotakkan pada ranah pribadi-Nya tetapi diekspresikan juga melalui praksis sosial kepada sesama manusia.

Ketiga, praksis kehadiran Kerajaan Allah yang digagas Kristus melalui prinsip integrasi yang holistik. Prinsip integrasi tidaklah memilah melalui menyamakan (equalization) ataupun membedakan (polarization) diantara kesaksian Injil dan keterlibatan sosial. Model praksis menghadirkan Kerajaan Allah, mengintegrasikan keduanya sebagai bagian penting dalam transformasi. Tidak ada dalam teks yang mengindikasikan anggapan superior atau inferior diantara satu dari yang lainnya. Kristus melakukannya secara utuh, holistik, tanpa upaya pemisahan. Dibutuhkan paradigma berpikir bahwa keterlibatan sosial bukanlah upaya kristenisasi, bukan juga untuk menggiring orang menjadi Kristen. Social concern adalah pengejawantahan Kerajaan Allah dan bentuk 
miniatur Injil. ${ }^{40}$ Sehingga tindakan sosial nilainya tidak lebih rendah dari pemberitaan Injil. Keduanya adalah bagian esensi kehadiran Kerajaan Allah yang tidak bisa saling disubstitusikan, sebaliknya harus digenapi utuh untuk dilakukan. Keprihatinan sosial merupakan sesuatu yang inheren sebagai etika sosial Kerajaan Allah dan bukan sekedar akibat pengalaman Kelahiran Baru. Meskipun demikian harus dicatat bahwa tindakan sosial, tidaklah cukup dan tidak akan mampu membawa orang pada keselamatan. Sebaliknya, pemberitaan Kerajaan Allah tanpa social concern tidaklah utuh dan hanya bersifat spasial.

Keempat, Gereja sebagai penerus untuk memegang tongkat estafet warisan (legacy) yang telah dibangun oleh Kristus. Peran gereja sebagai agen transformasi tidak bisa kurang dari apa yang menjadi model praksis Yesus. Melalui pendekatan praksis Yesus, Gereja perlu terlibat untuk memberikan solusi sosial yang menggurita dari dunia virtual dan dunia fisik di masyarakat era 5.0. Gereja hadir tidak hanya untuk komunitasnya tetapi juga bagi masyarakat dan lingkungannya. Peran ini nampak seperti yang tertulis pada Yohanes 18:36, bahwa Gereja bukan dari dunia tetapi Gereja ada dalam dunia mengimplementasikan perannya. Sehingga tidaklah terhindarkan jika Gereja harus mengambil bagian terlibat dalam rekonstruksi sosial di dalam krisis sosial pada abad ke-21. ${ }^{41}$ Tujuannya untuk membangun masyarakat yang lebih baik, beradab dan berkeadilan. Hal ini bukanlah suatu produk jadi tetapi dicapai dengan usaha dan kerja keras. Tidak juga bisa dicapai hanya dengan pemberitaan di mimbar, tetapi masuk dan menyatu dengan masyarakat dalam upaya perubahan dan pembaharuan. Suatu usaha yang dilakukan dengan holistik, utuh dan tidak spasial, khususnya untuk suatu masa depan Indonesia yang lebih baik.

Penelitian ini terfokus hanya menganalisis prinsip transformasi kehadiran Kerajaan Allah

\footnotetext{
${ }^{40}$ Stott, John R.W. and Wright, Christian mission in the modern world.

${ }^{41}$ Walter Rauschenbusch dan Paul Rauschenbusch, Christianity and the social crisis in the 21st century: The classic that woke up the church (New Yoprk: HaperCollis e-books, 2007).
}

melalui praksis yang digagas Yesus. Masih ada bagian lain yang dirasa penting dan tidak banyak disentuh, khususnya menyangkut bentuk-bentuk implementasi praktis. Nampaknya dibutuhkan elaborasi lanjutan, khususnya berkaitan dengan penjabaran praksis yang digagas Yesus. Adapun tujuannya agar penelitian bisa ditindaklanjuti pada ranah konkret dan praktis oleh Gereja.

\section{KEPUSTAKAAN}

Azis, M. A. "Pengembangan Satuan Unit Cyber Crime." Jurnal Litbang POLRI 22, no. 1 (2019): 408-459.

Bosch, David J. Transforming mission: Paradigm shifts in theology of mission. Orbis books, 2011.

Budiman, Stefanus Rachmat. "Problem Keadilan Sosial Dalam Nubuat Kitab Mika." Jurnal Transformasi 14, no. 1 (2019): 101-115.

Foster, Richard J. Money, Sex $\mathcal{E}$ Power: The Challenge of the Disciplined Life. San Francisco: Harper \& Row Publisher, 1985.

Gomez, Jeff. Print is dead: Books in our digital age. Palgrave Macmillan, 2008.

Gorman, Michael J. Elements of biblical exegesis: A basic guide for students and ministers. Baker Academic, 2020.

Harming, Harming. "Metode Penginjilan Yesus Dalam Injil Yohanes 4: 1-42.” Evangelikal 1, no. 2 (2017): 162-169.

Hunter, A. M. Memperkenalkan Teologi Perjanjian Baru. Jakarta: BPK Gunung Mulia, 1999.

Isetti, Giulia, Elisa Innerhofer, Harald Pechlaner, dan Michael De Rachewiltz. Religion in the Age of Digitalization. New York: Routledge, 2021.

Ladd, George Eldon. Injil Kerajaan. Yayasan Penerbit Gandum Mas, 1994.

Maggay, Melba Padilla. Transformasi Masyarakat: Refleksi Keterlibatan Sosial Kristen. Edisi pert. Jakarta: Cultivate Publishing, 2004.

Matsuura, Jeffrey H. Managing intellectual assets in the digital age. Artech House, 2003.

Nastiti, Faulinda Ely, dan Aghni Rizqi Nimal Abdu. "Kajian: Kesiapan pendidikan Indonesia menghadapi era society 5.0.” 
Edcomtech 5, no. 1 (2020): 61-66.

Nayuf, Hendrikus. "Mewartakan Injil - Menahan

Roti: sebuah Catatan Kritis Atas Model

Pelayanan Yudas." BIA': Jurnal Teologi dan

Pendidikan Kristen Kontekstual 1, no. 2 (2018): 191-203.

Panggarra, Robi. "Kerajaan Allah Menurut InjilInjil Sinoptik.” Jurnal Jaffray 11, no. 1 (2013): 109-128.

Pillay, Jerry. "The church as a transformation and change agent." HTS Theological Studies 73, no. 3 (2017): 1-12.

Priana, I Made. "Misi Gereja Menghadirkan Kerajaan Allah di Bumi." SANCTUM DOMINE: JURNAL TEOLOGI 4, no. 1 (2016): 12-27.

Putra, Adi. "Memahami Bangsa-bangsa Lain dalam Injil Matius." BIA': Jurnal Teologi dan Pendidikan Kristen Kontekstual 1, no. 2 (2018): 243-252.

Rauschenbusch, Walter, dan Paul Rauschenbusch. Christianity and the social crisis in the 21st century: The classic that woke up the church. New Yoprk: HaperCollis ebooks, 2007.

Salurante, Tony, Dyulius Th Bilo, dan David Kristanto. "Transformasi komunitas misi: Gereja sebagai ciptaan baru dalam Roh Kudus.” KURIOS (Jurnal Teologi dan Pendidikan Agama Kristen) 7, no. 1 (2021): 136-148.

Selwyn, Neil, Stephen Gorard, dan John Furlong. Adult learning in the digital age: Information technology and the learning society. Routledge, 2006.

Setiawan, David Eko. "Dampak Injil Bagi Transformasi Spiritual Dan Sosial.” BIA': Jurnal Teologi dan Pendidikan Kristen Kontekstual 2, no. 1 (2019): 83-93.

Setiawan, Dian Alan. "Perkembangan Modus Operandi Kejahatan Skimming Dalam Pembobolan Mesin Atm Bank Sebagai Bentuk Kejahatan Dunia Maya (Cybercrime)." Era Hukum-Jurnal Ilmiah Ilmu Hukum 16, no. 2 (2019).

Simamora, Ridwan Henry. "Gereja Dan Transformasi Kristen Suatu Tinjauan Kristis Terhadap Misi Gerakan
Transformasi." Missio Ecclesiae 2, no. 1 (2013): 85-110.

Solove, Daniel J. The future of reputation. Yale University Press, 2008.

Stevanus, Kalis. "Mengimplementasikan Pelayanan Yesus dalam Konteks Misi Masa Kini Menurut Injil Sinoptik.” FIDEI: Jurnal Teologi Sistematika dan Praktika 1, no. 2 (2018): 284-298.

Stott, John R.W. and Wright, Christopher J. H. Christian mission in the modern world. Downers Grove: InterVarsity Press, 2015.

Susanta, Yohanes Krismantyo. "Gereja Sebagai Persekutuan Persahabatan Yang Terbuka Menurut Jürgen Moltmann." Visio Dei: Jurnal Teologi Kristen 2, no. 1 (2020): 105126.

Susanto, H. "Panggilan Sosial Gereja Berdasarkan Pelayanan Yesus dalam Lukas 4:18-19: Sebuah Upaya Merevitalisasi Pelayanan Gereja." Veritas: Jurnal Teologi Dan Pelayanan 19, no. 1 (2020): 97-112.

Wijaya, Hengki. "Misi Dan Pelayanan Sosial: Manakah yang lebih Penting?" In Sekolah Tinggi Theologia Jaffray, 120-144. Sekolah Tinggi Theologia Jaffray, 2017. 